\title{
Treading softly on the ozone layer
}

\begin{abstract}
$A$ long-awaited report on the environmental effects of halocarbons was published in the United States last week. Colin Norman and Chris Sherwell report from Washington
\end{abstract}

THE US National Academy of Sciences (NAS) last week added its powerful voice to the scientific and political dispute about whether halocarbons, spewed into the atmosphere chiefly from aerosol spray cans, are causing serious damage to the Earth's ozone layer. The general press seemed to have some difficulty in deciding just what message the Academy was trying to convey, however. "Scientists Back New Aerosol Curbs to Protect Ozone in Atmosphere" ran the headline in the New York Times. "Aerosol Ban Opposed by Science Unit", said the Washington Post. Both were in fact correct, and the contrast reflects the finely balanced nature of the Academy's conclusions and recommendations.

The chief conclusion, set out in a long-awaited report by the NAS Committee on Impacts of Stratospheric Change, is that significant deterioration of the ozone layer will eventually occur if halocarbons continue to be released at their present rate. That would allow more ultraviolet radiation to reach the Earth's surface which, in turn would cause additional cases of skin cancer and other biological damage. Moreover, the committee warned of a possible effect on the world's climate from any continuing build-up of halocarbons in the atmosphere.

Alarming though such prospects may be, the committee cautions against taking precipitate action, such as banning the use of halocarbons as propellants in aerosol products. Instead, although it acknowledges that regulation is "almost certain to be necessary at some time and to some degree of completeness", the committee recommends that key uncertainties in the calculations should be cleared up before uses of halocarbons are restricted. The necessary information should be gathered in less than two years, the committee argues, and such a delay will cause little additional damage to the ozone layer.

The NAS recommendations were greeted with restrained enthusiasm by the halocarbon industry, and by the makers of hair sprays, deodorants and similar cosmetic products which together account for the major uses of the material. The industry-sponsored
Council on Atmospheric Sciences said in a statement last week, for example, that the report backs the industry's view that "more research is required before any national decision on the fluorocarbon issue can be reached". Some scientists and environmentalist groups were not so happy, however. A spokesman for the Natural Resources Defense Council noted, for example, that the NAS recommendation for a two-year delay in regulation "is a value judgment which scientists are no better equipped to make than anybody else". Clearly, publication of the report will not put an end to the controversy which has been raging over the ozone depletion theory for the past couple of years.

The theory was first advanced in 1974 by two scientists from the University of California, F. Sherwood Rowland and Mario J. Molina (Nature, 249, 810; 1974). They argued, in short, that the very properties which make halocarbons so useful-their insolubility and inertness-also pose a problem : unlike most airborne pollutants, they are not washed out of the lower atmosphere by rain. They gradually drift up into the stratosphere, where they are broken down by sunlight, releasing free chlorine atoms which break down ozone molecules through a complex series of chain reactions.

If that sequence of events is actually taking place, the result would be a reduction in the concentration of ozone in the stratosphere, and a consequent increase in the amount of harsh ultraviolet radiation reaching the Earth's surface. The ultimate consequence would be an increase in the incidence of skin cancer, which is correlated with exposure to sunlight, and possible biological damage to plants and anjmals.

Publication of the theory ignited a scientific and political controversy as some scientists attacked it as being implausible, while others argued that it is frighteningly realistic. The implications for human health also led to suggestions that the use of aerosol sprays be curbed, and prompted a massive research effort to test the validity of the theory.

Then, earlier this year, yet another alarming theory was put forward, namely, that accumulation of halocarbons in the atmosphere will result in a so-called "greenhouse effect", increasing the Earth's temperature and perhaps altering its climate.

The NAS committee has thus been poring over a mass of information accumulated since Rowland and Molina published their theory, and its report has been delayed for nearly six months by the appearance of important and conflicting pieces of data. In the end, however, the committee concluded that the evidence produced so far supports the ozone depletion theory. According to the committee's Chairman, John Tukey, a statistician from Princeton University and Bell Laboratories, the mechanism is now "a relatively well understood process".

It should be noted at this point, however, that it is impossible to test the theory by direct measurements of ozone concentration in the stratosphere since available measuring techniques are too insensitive to detect relatively small, long-term variations in the ozone layer. The theory is therefore based on laboratory experiments and computer analyses, supplemented with direct measurements of the atmospheric concentration of various key links in the chain reaction, such as chlorine, hydrogen chloride and so on. The whole business is a little like building up a jigsaw puzzle from badly cut and incomplete pieces.

Nevertheless, the committee has concluded that, if halocarbons continue to be spewed into the atmosphere at the rate they were released in 1973, the ultimate effect would be to reduce the concentration of ozone in the stratosphere by about $7 \%$. It will take several decades to reach that level of depletion, however, since once released into the atmosphere, halocarbons can take up to a century to reach the stratosphere to do their work.

The figure of about $7 \%$ is deceptively precise. In fact, Tukey was careful to point out last week that it may turn out to be as low as $2 \%$ or as high as $20 \%$, the uncertainties being caused by the complexity of the reactions - as many as 30 or 40 may be involved-and by the incompleteness of the information so far accumulated. That's one reason why the committee recommended against an immediate ban on nonessential uses in aerosols and suggested that more data are required.

Even if all release of halocarbons were to cease immediately, the committee has calculated that the material already in the lower atmosphere would continue to rise into the stratosphere and increase the destruction of the ozone layer for at least a decade. The ozone layer would then recover very slowly, with only half of the reduction being restored in 50 years. As for the consequences of delaying regulation by two years, the committee has calculated that if the figure of $7 \%$ reduction is correct, "whether a halving in (halocarbon) use and release were to take place in 1977 or 1979 would alter the 
ozone reduction at any later date by no more than $1 / 6$ per cent". In other words, "costs of delay in decision are small, not more than a fraction of a percent change in ozone depletion for a couple of years' delay".

Some perspective on the uncertainties in these calculations can be gained from a brief look at the problems which the committee encountered in putting out its report. The report was originally scheduled for publication in April but just as it was being put together, some new information, which seemed to throw the whole basis of the ozone depletion theory out of the window, suddenly came to light. In short, the theory would fall apart if there is a natural process which ties up chlorine atoms before they can attack the ozone molecules in the stratosphere. It seemed for a few weeks that just such a mechanism had been discovered. The suggested mechanism was the formation of chlorine nitrate, a compound which may be relatively stable under stratospheric conditions from chlorine atoms liberated from halocarbons and oxides of nitrogen already in the stratosphere.

When calculated rates of formation of chlorine nitrate were slotted into the equations, it turned out that halocarbons may even have a positive effect on the ozone layer-in other words, they may increase ozone concentration by removing oxides of nitrogen from the stratosphere. Later computations indicated, however, that the assumed rate of formation of chlorine nitrate had been greatly overestimated, and the effect of the mechanism is actually quite small.

As for the potential climatic effects of halocarbons, the committee suggests that precise information is equally hard to come by. Nevertheless, its best guess is that there will be a warming effect due to absorption of infrared radiation by halocanbons in the atmosphere, the effect being similar to that proposed for carbon dioxide accumulated through the burning of fossil fuels. Tukey suggested that the effect from halocarbons in the year 2000 might be about $40 \%$ of that due to burning fossil fuels, but he added that the relationship between such warming trends and broader climate changes is very poorly understood. "There are going to be some climate effects and it would be, I think, a disservice to puit hard numbers on them this year", he said.

Although the committee recommends against immediate restrictions on the use and release of halocarbons, it does urge a number of steps to prepare the way for regulation should it be needed. At present, the authority to regulate the use of aerosol sprays is vested in at least three different agencies - the Food and Drug Adminis- tration (FDA) the Environmental Protection Agency (EPA) and the Consumer Product Safety Commission (CPSC)-and it is questionable whether any of them really has a powerful enough mandate to act. Legislation is clearly required. Last week, by coincidence, Congress finally approved the Toxic Substances Control Act, a legislative landmark which, according to some interpretations, may provide EPA with enforceable authority over halocarbons. But the Bill is opposed by industry and may be vetoed by President Ford. Similarly, Congress is close to passing a series of amendments to the Clean Air Act, which again would give EPA a powerful lever to regulate aerosol products. The problem here, however, is that the House and Senate may not be able to settle some basic disagreements on other parts of the Bill before the October 2 recess. Thus, legislation may have to wait until next year.

The committee does, however, recommend one potentially important step which could be implemented relatively quickly. It suggests that aerosol sprays containing halocarbon propellants should bear a label stating that fact. The FDA, which has authority to regulate cosmetics, probably has the power to enforce such labelling. Though the committee argues that

Estimated worldwide releases of F-11 and F-12 in 1975 (millions of pounds)

\begin{tabular}{|c|c|c|c|}
\hline \multirow{3}{*}{$\begin{array}{l}\text { Aerosols } \\
\mathbf{1 1 1 5 . 1} \\
(74.5 \%)\end{array}$} & Personal & $\left\{\begin{array}{l}\text { Antiperspirants/deodorants } \\
\text { Hair care } \\
\text { Medicinal } \\
\text { Fragrances } \\
\text { Shave lathers } \\
\text { Others }\end{array}\right.$ & $\begin{array}{r}458.4 \\
401.5 \\
37.3 \\
2.3 \\
0.9 \\
34.4\end{array}$ \\
\hline & Household & $\left\{\begin{array}{l}\text { Room deodorants } \\
\text { Cleaners } \\
\text { Laundry products } \\
\text { Waxes and polishes } \\
\text { Others }\end{array}\right.$ & $\begin{array}{r}17.7 \\
9.6 \\
23.4 \\
9.2 \\
9.2\end{array}$ \\
\hline & Miscellaneous & $\left\{\begin{array}{l}\text { Insecticides } \\
\text { Coatings } \\
\text { Industrial } \\
\text { Automotive } \\
\text { Vet. and Pet } \\
\text { Others }\end{array}\right.$ & $\begin{array}{r}33.3 \\
22.9 \\
39.0 \\
8.0 \\
2.3 \\
5.7\end{array}$ \\
\hline $\begin{array}{l}\text { Air conditioning } \\
\text { refrigeration } \\
\mathbf{2 0 4 . 7} \\
(13.7 \%)\end{array}$ & & $\left\{\begin{array}{l}\text { Mobile air conditioning } \\
\text { Chillers } \\
\text { Food store } \\
\text { Beverage coolers } \\
\text { Home refrigerators and freezers } \\
\text { Miscellaneous }\end{array}\right.$ & $\begin{array}{r}89.8 \\
42.9 \\
33.1 \\
5.8 \\
5.8 \\
27.3\end{array}$ \\
\hline \multirow[t]{2}{*}{$\begin{array}{l}\text { Plastic foams } \\
\quad 176.5 \\
(11.8 \%)\end{array}$} & & $\begin{array}{l}\text { Open cell } \\
\text { Closed cell }\end{array}$ & $\begin{array}{r}100.0 \\
76.5\end{array}$ \\
\hline & & Tot & 1496.3 \\
\hline
\end{tabular}

Figures are based on the annual incremental releases of F-11 and F-12 indicated for 1975 in a 1976 report by the Manufacturing Chemists Association, and the detailed percentage analysis by users in the US for 1973 in a 1975 report by Arthur D. Little, Inc. for the EPA. Figures do not include USSR and Eastern Europe.

Breakdown between F-11 and F-12 not available. If $\mathrm{F}-11\left(\mathrm{CFCl}_{3}, 77 \%\right.$ chlorine by weight) could be replaced by an equal weight of $\mathrm{F}-12\left(\mathrm{CF}_{2} \mathrm{Cl}_{2}, 59 \%\right.$ chlorine by weight $)$-not often feasible--the amount of ozone reduction would be decreased.

Source: Halocarbons: Environmental Effects of Chlorofluoromethane Release, Chapter 1 and Appendix D. "labeling should in no sense be rearded as a substitute for regulation large, since consumers are already beginning to turn away from some erosol products. In 1975, for example, - the first decline in more than a decade (the accompanying table shows 975 figures).

As for the effects on industry of a can be gleaned from the fact that total world production of the two halocarbons with which the committee is to nearly one million tonnes. But, says the committee, the industrial consequences do "not loom large" against ery small, change in world climate".

Finally, it should be noted that the US accounts for almost half the total world use of halocarbons. Thus, if the it would only attack half of the problem. The committee therefore recomencer countries should be means are likely to be effective" to take similar action. restraint", the effect could be rather and $\mathrm{CF}_{2} \mathrm{Cl}_{2}$ or $\mathrm{F}-12$ - amounted in 1974 